Vanhaecke, P., Tackaert, W. \& Sorgeloos, P. 1987. The biogeography of Artemia: an updated review. In Sorgeloos, P., Bengtson, D.A., Decleir, W. \& Jaspers, E. (Eds.), Artemia: Research and its applications, vol. 1. 359 pp. Universa Press, Belgium.

Verrill, A.E. 1869a. Descriptions of some new American Phyllopod Crustacea. American Journal of Science and Arts, (2)48: 244-254.

Verrill, A.E. 1869b. New localities of Artemia. American Journal of Science and Arts, (2)48: 430.

Yaneng, C. 1989. New Artemia sibling species from PR China. Artemia Newsletter, 11(January): $40-41$. 
Case 2720

\title{
Dalla Mabille, 1904 (Insecta, Lepidoptera): proposed conservation
}

\author{
Stephen R. Steinhauser, Lee D. Miller \& Jacqueline Y. Miller \\ Allyn Museum of Entomology, The Florida Museum of Natural History, \\ 3621 Bay Shore Road, Sarasota, Florida 34234, U.S.A.
}

\section{Charles A. Bridges}

502 West Main Street, Apt. 308, Urbana, Illinois 61801, U.S.A.

\begin{abstract}
The purpose of this application is to conserve the name Dalla Mabille, 1904 for a hesperiid (skipper) butterfly genus by suppression of the seldom used senior subjective synonym Eumesia Felder \& Felder, [1867].
\end{abstract}

1. In 1867, Felder \& Felder established a new genus Eumesia (p. 504) with a single nominal species semiargentea (p. 505) which is, therefore, the type species by monotypy. The species was based on a hesperiid specimen from Colombia with the attached head of a satyrid butterfly. The specimen, which they failed to recognize as an artefact, is now in the British Museum (Natural History) collections, registered as Rothschild Bequest, BM 1939-1, type no. H-1098. Felder \& Felder ([1867], p. 504) also proposed a new family EUMESIIDAE as an intermediate familial group between HESPERIDAE and SATYRIDAE, an action resulting only from their failure to recognize the composite nature of the holotype.

2. In 1904, Mabille (p. 107) established a new genus Dalla in which he placed 47 species (eight of which he had not seen and two of which he listed as of uncertain status) plus five additional names as synonyms. He (p. 108) recognized Eumesia as a valid genus with semiargentea as the sole species, but did not make clear what he considered to be the significant difference between Eumesia and Dalla. Mabille \& Boullet (1908, $1912,1919)$ never finished their revision of the HESPERIIDAE, and their treatment of Eumesia and Dalla was not stated. Lindsey (1921, p. 58) designated Cyclopides eryonas Hewitson, 1877 (p. 325) as the type species of Dalla.

3. Evans (1955, p. 19) was the first worker to recognize the synonymy of Eumesia and Dalla. His action is described by Hemming (1967, p. 177) in the following terms:

'Evans treated this generic name [Eumesia] in a strange and entirely incorrect manner. He accepted the nominal species Eumesia semiargentea as representing a taxonomically distinct species. In spite of this he rejected the generic name Eumesia on the ground that the holotype of its type species (Eumesia semiargentea) now in the British Museum was a specimen which had lost its head and on which in place of the missing head the head of some Satyrid species had been gummed. Evans's ground for rejecting this generic name was that the substitution of this false head on the holotype vitiated the generic diagnosis given by the authors of this name. This action was misconceived, there being nothing in the Code to authorize the 
rejection of a generic name on such grounds. Moreover, Evans's contention was incorrect in fact, for only part of the original diagnosis. was concerned with the characters of the head. Quite apart from this consideration, Evans forgot that prior to 1931 it was not necessary for an author to provide any diagnosis for a new genus, provided that he included in the genus one or more duly established nominal species. This condition was duly complied with by the authors of this generic name. The name Eumesia is therefore an available name, and accordingly Evans's action in rejecting it was invalid'.

Hemming (1967) did not himself comment on the possible subjective synonymy of Eumesia and Dalla. He treated both Eumesia (p. 177) and Dalla (p. 138) as valid generic names, although he did not consider the taxonomy.

4. Bridges (1983 (II), pp. 13, 14; 1988 b (II), p. 22) accepted Hemming's treatment of Eumesia as an available name. He recognized Eumesia as a senior synonym of Dalla and placed in Eumesia all the species that Evans (1955, pp. 18-44) had included in Dalla, including its type species eryonas. However, he did list under Dalla (1983 (II), p. 11; 1988b (II), p. 18) four names published since Evans' work, but this inconsistent action was a simple 'lapsus', understandable in such a massive undertaking. Bridges (1988c (5), pp. 1-6), having seen the proposals to the Commission in a draft of this application, has emended his earlier treatment and placed all relevant taxa (including semiargentea) in Dalla, eliminating Eumesia completely. He has asked to be included as a co-author of this application.

5. Since its publication in 1867, the name Eumesia has been used exclusively in conjunction with its type species semiargentea with two exceptions: Erschoff (1876, pp. 140-149, pl. 3, fig. 6) who described Eumesia jelskyi, and Bridges $(1983,1988$ b) as set out in para. 4 above. Dalla, on the other hand, has been used since 1904 in the description of new species by at least eight authors in ten separate publications (e.g. Dalla seirocastnia Draudt, [1923], p. 923; Dalla frontinia Evans, 1955, pp. 25-26; Dalla pota Bell, 1959, p. 1) as well as in a number of catalogue-type compilations.

6. The family-group name EumESIIDAE Felder \& Felder, [1867] has not been used since its description in any of the relevant taxonomic literature or in any cataloguetype compilations. It is a senior subjective synonym of HETEROPTERINAE Aurivillius, 1925 (pp. 506, 546) which is based on the well known Palearctic genus Heteropterus Duméril, 1806 (p. 271). HETEROPTERINAE has been used by a number of authors including Aurivillius (see above); Higgins, 1975, p. 51; Miller \& Brown, 1981, p. 26; Bridges, 1988a (II), p. 1.

7. To reintroduce usage of the generic name Eumesia and the family-group name EUMESIIDAE would not be in the interests of nomenclatural stability. This family-group name would cease to be available on suppression of the name of the type genus, Eumesia.

8. The International Commission on Zoological Nomenclature is accordingly asked:

(1) to use its plenary powers to suppress the generic name Eumesia Felder \& Felder, [1867] for the purposes of the Principle of Priority but not for those of the Principle of Homonymy;

(2) to place on the Official List of Generic Names in Zoology the name Dalla Mabille, 1904 (gender: feminine), type species by subsequent designation by Lindsey (1921) Cyclopides eryonas Hewitson, 1877; 
(3) to place on the Official List of Specific Names in Zoology the name eryonas Hewitson, 1877, as published in the binomen Cyclopides eryonas (specific name of the type species of Dalla Mabille, 1904);

(4) to place on the Official Index of Rejected and Invalid Generic Names in Zoology the name Eumesia Felder \& Felder, [1867], as suppressed in (1) above;

(5) to place on the Official Index of Rejected and Invalid Family-Group Names in Zoology the name EUMESIIDAE Felder \& Felder, [1867] (type genus Eumesia Felder \& Felder, [1867]) (name of the type genus suppressed in (1) above).

\section{References}

Aurivillius, P.O.C. 1925. Family Hesperidae in Seitz, A., (Ed.), The Macrolepidoptera of the World. Vol. 13. 613 pp. Kernan, Stuttgart.

Bell, E.L. 1959. Descriptions of some new species of Neotropical Hesperiidae (Lepidoptera: Rhopalocera). American Museum Novitates, No. 1962: 1-16.

Bridges, C.A. 1983. Lepidoptera: Hesperiidae, Notes on species-group names. (I): 1-129; (II): 2-41; (III): 1-62; (IV): 1-30; (V): 1-13. Privately published, Urbana.

Bridges, C.A. 1988a. Catalogue of family-group and genus-group names (Lepidoptera: Rhopalocera). (I): 1-8; (II): 1-3; (III): 1-4; (IV): 1-130; (V): 1-33; (VI): 1-67; (VII): 1-18; (VIII): 1-59; (IX): 1-20; (X): 1-8. Privately published, Urbana.

Bridges, C.A. 1988b. Catalogue of Hesperiidae (Lepidoptera: Rhopalocera). (I): 1-205; (II): 1-67; (III): 1-78; (IV): 1-54; (V): 1-20; (VI): 1-7; (App. I): 1; (App. II): 1-8. Privately published, Urbana.

Bridges, C.A. 1988c. Annotations on the Catalogue of Hesperiidae. (1): 1; (2): 1; (3): 1-4; (4): 1-2; (5): 1-6. Privately published, Urbana.

Draudt, M. [1923]. Family Hesperidae in Seitz, A. (Ed.), The Macrolepidoptera of the World, 5: 836-1011, 1046-1055. Kernan, Stuttgart.

Duméril, A.M.C. 1806. Zoologie Analytique, ou Méthode naturelle de Classification des Animaux. 344 pp. Allais, Paris.

Erschoff, N.G. 1876. [Descriptions of new species of exotic Lepidoptera]. Trudy Russkago Entomologicheskago Obshchestva, 8: 140-149. [In Russian.]

Evans, W.H. 1955. A Catalogue of the American Hesperiidae in the British Museum (Natural History). Part 4: Hesperiinae and Megathyminae. 499 pp. British Museum, London.

Felder, C. \& Felder, R. 1865-1867. Rhopalocera, in Reise der Österreichischen Fregatte 'Novara' um die Erde. 549.pp. Der Kaiserlich-Königlichen Hof- und Staatsdruckerei, Wien.

Hemming, F. 1967. The generic names of the butterflies and their type species (Lepidoptera: Rhopalocera). Bulletin of the British Museum (Natural History). Entomology, Supplement 9: 1-509.

Hewitson, W.C. 1877. Descriptions of twenty three new species of Hesperidae from his own collection. Annals and Magazine of Natural History, (4)20: 319-328.

Higgins, L.G. 1975. The Classification of European Butterflies. 320 pp. Collins, London.

Lindsey, A.W. 1921. The Hesperioidea of America North of Mexico. University of Iowa Studies in Natural History, 9(4): 1-114.

Mabille, P. 1904. Lepidoptera Rhopalocera. Fam. Hesperidae. Genera Insectorum, 17: 1-210.

Mabille, P. \& Boullet, E. 1908. Essai de révision de la famille des Hespérides. Annales des Sciences Naturelles Zoologie, (9)7: 167-207.

Mabille, P. \& Boullet, E. 1912. Essai de révision de la famille des Hespérides. 2. Subfamily Hesperiinae. Annales des Sciences Naturelles Zoologie, (9)16: 1-159.

Mabille, P. \& Boullet, E. 1919. Essai de révision de la famille des Hespérides. Annales des Sciences Naturelles Zoologie, (10)2: 199-258.

Miller, L.D. \& Brown, F.M. 1981. A catalogue/checklist of the butterflies of America north of Mexico. 280 pp. The Lepidopterists' Society, Memoir No. 2, Sarasota, Florida. 


\section{$2 \mathrm{BHL}$ Biodiversity Heritage Library}

Rognes, K and Blackith, R. E. 1990. "Calliphora vicina Robineau-Desvoidy, 1830 (Insecta, Diptera): proposed conservation of the specific name." The Bulletin of zoological nomenclature 47, 187-190. https://doi.org/10.5962/bhl.part.2708.

View This Item Online: https://www.biodiversitylibrary.org/item/44488

DOI: https://doi.org/10.5962/bhl.part.2708

Permalink: https://www.biodiversitylibrary.org/partpdf/2708

\section{Holding Institution}

Natural History Museum Library, London

\section{Sponsored by}

Natural History Museum Library, London

\section{Copyright \& Reuse}

Copyright Status: In copyright. Digitized with the permission of the rights holder.

License: http://creativecommons.org/licenses/by-nc-sa/3.0/

Rights: https://biodiversitylibrary.org/permissions

This document was created from content at the Biodiversity Heritage Library, the world's largest open access digital library for biodiversity literature and archives. Visit BHL at https://www.biodiversitylibrary.org. 